\title{
Psychopharmacology of ADHD in pediatrics: current advances and issues
}

\author{
Donald E Greydanus \\ Ahsan Nazeer \\ Dilip R Patel
}

Michigan State University College of Human Medicine, Michigan State University/Kalamazoo Center for Medical Studies, Kalamazoo, MI, USA
Correspondence: Donald E Greydanus Professor, Pediatrics and Human Development, Michigan State University College of Human Medicine, Pediatrics Program Director, Michigan State University/Kalamazoo Center for Medical Studies, Kalamazoo, MI 49008-I 284, USA

Tel +269-337-6450

Fax+269-337-6474

Email greydanus@kcms.msu.edu

\begin{abstract}
Attention deficit hyperactivity disorder (ADHD) is a neurobehavioral developmental disorder found in 3\% to $8 \%$ of children and adolescents. An important part of ADHD management is psychopharmacology, which includes stimulants, norepinephrine reuptake inhibitors, alpha-2 agonists, and antidepressants. Medications with the best evidence-based support for ADHD management are the stimulants methylphenidate and amphetamine. A number of newer, long-acting stimulants are now available and a number of new medications are considered that are under current research.
\end{abstract}

Keywords: ADHD, methylphenidate, amphetamine, norepinephrine reuptake inhibitors, alpha-2 agonists, antidepressants

\section{Introduction}

Attention deficit hyperactivity disorder (ADHD) is a neurobehavioral developmental disorder with neurotransmitter dysfunction of the noradrenergic, dopaminergic, and serotonergic systems. It is present in $3 \%$ to $8 \%$ of children and adolescents and has characteristics of inattentiveness with or without impulsivity. ${ }^{1-6}$ A thorough history and physical examination is necessary to make this diagnosis. ${ }^{7-9}$ Management includes providing appropriate psychological therapy, insuring proper school placement, and, if necessary, judicious use of anti-ADHD medications. ${ }^{1,2}$ This report summarizes current concepts in ADHD psychopharmacology specifically the use of stimulants, alpha-2 agonists, and anti-depressants. Other medications under research are also considered.

\section{Stimulant medications}

Research in the 20th century revealed that stimulant medications were useful in improving attentional dysfunction in children and adolescents. ${ }^{10}$ Indeed, hundreds of studies conducted over the past $60+$ years have consistently demonstrated the effectiveness of stimulant medications in improving attention dysfunction associated with ADHD in children, adolescents, and adults. ${ }^{11-20}$ Research notes improvement in concentration ability in $75 \%$ to $95 \%$ of those with ADHD on stimulants. The success of this pharmacologic approach has resulted in increasing use of stimulants for ADHD with $6 \%$ of pediatric patients 5 to 15 years of age being placed on stimulant medication in the United States. ${ }^{21,22}$

\section{Methylphenidate} General considerations

MPH (methylphenidate) has been available in the United States since the late 1950s and has become the most common stimulant medication used to treat ADHD because of its beneficial effect on problems with concentration. Its pharmacologic effects are based on selective binding of the presynaptic dopamine transporter in the central 
nervous system (particularly the striatal and prefrontal areas) that result in a rise in extracellular dopamine in the central nervous system (CNS). ${ }^{14,20,23}$ Table 1 lists medications used to treat ADHD that have evidence-based research and notes their dosages and common side effects.

MPH is a schedule II medication produced in short-acting and long-acting oral formulations (Table 2). Short-acting MPH is marketed as Ritalin ${ }^{\circledR}$ (and other brand names) or its generic version and after oral ingestion, pharmacologic action is noted in 30 to 45 minutes that peaks in 1 to 2 hours, and fades away over 3 to 5 hours. This short acting formulation requires one to three doses a day as desired by the child or adolescent to improve attentional dysfunction. One should not exceed a single dose over $20 \mathrm{mg}$ or a daily dosage over 60 to $80 \mathrm{mg}$ while the patient is titrated to the dosage regimen best suited for him or her.

\section{MPH preparations}

After the development of MPH as a short-acting stimulant, a longer-acting product became available, Ritalin $\mathrm{SR}^{\circledR}$.
It comes as a $20 \mathrm{mg}$ sustained released tablet that results in a release of about $7 \mathrm{mg}$ of short-acting MPH over several hours. Since Ritalin $\mathrm{SR}^{\circledR}$ only comes in a $20 \mathrm{mg}$ tablet and unpredictable gastrointestinal absorption is noted in half of its users, pharmaceutical companies launched a search for additional MPH products, mostly those with a longeracting effect. Table 2 lists these newer longer-acting MPH products while Table 3 notes reasons for failure of benefit from psychostimulant medications. ${ }^{1,6,11-19}$ Though there has been intense advertising by the manufacturers of these newer products that one is better than another or that longacting formulations are "better" than short-acting, there is no neutral scientific evidence to sustain such statements. A trial and error method is necessary to determine what specific product or products are best for a specific child or adolescent with ADHD. Some of these newer products are discussed below.

An MPH patch (Daytrana ${ }^{\circledR}$ ) was released in June 2006 and allows effect for up to 12 hours; it is applied in the morning and removed in the afternoon or evening, providing

Table I Medications with research support for use in attention disorders

\begin{tabular}{|c|c|c|}
\hline Medication & Daily dose $(\mathrm{mg} / \mathrm{kg})$ schedule & Common untoward effects \\
\hline \multicolumn{3}{|l|}{ Stimulants } \\
\hline Methylphenidate & $\begin{array}{l}0.3-2.0(10-80 \mathrm{mg} / \text { day }) \text { in } 2-4 \text { divided } \\
\text { doses }\end{array}$ & $\begin{array}{l}\text { Insomnia, decreased appetite, abdominal pain, } \\
\text { headache, depression, loss of weight, rebound } \\
\text { symptoms, decreased velocity versus growth delay. } \\
\text { See text }\end{array}$ \\
\hline Magnesium pemoline & $\begin{array}{l}0.5-3.0(37.5-131.25 \mathrm{mg} / \mathrm{day}) \\
\text { In } 1-2 \text { divided doses }\end{array}$ & $\begin{array}{l}\text { Same as methylphenidate }+ \text { possible liver toxicity } \\
\text { (new FDA Black Box warning) }\end{array}$ \\
\hline Dextroamphetamine & $\begin{array}{l}0.1-1.5(5-80 \mathrm{mg} / \text { day }) \text { in } 2-4 \text { divided } \\
\text { doses }\end{array}$ & Same as methylphenidate but more depression \\
\hline \multicolumn{3}{|l|}{ Antidepressants } \\
\hline $\begin{array}{l}\text { Tricyclic antidepressants } \\
\text { imipramine } \\
\text { desipramine } \\
\text { nortriptyline }\end{array}$ & $\begin{array}{l}1-5 \\
1-5 \\
0.5-3\end{array}$ & Anticholinergic effects, others. See text \\
\hline Bupropion & $\begin{array}{l}3-6(50-300 \mathrm{mg} / \text { day }) \text { in } 2-3 \text { divided } \\
\text { doses }\end{array}$ & $\begin{array}{l}\text { Insomnia, irritability, drug-induced seizures (with } \\
\text { doses }>6 \mathrm{mg} / \mathrm{kg} \text { ) } \\
\text { Contraindicated in bulimic patients }\end{array}$ \\
\hline \multicolumn{3}{|l|}{ Alpha-2 agonists } \\
\hline Clonidine & $\begin{array}{l}3-10 \mu g / \mathrm{kg}(0.05-0.4 \mathrm{mg} / \text { day }) \text { in } \\
2-4 \text { divided doses }\end{array}$ & $\begin{array}{l}\text { Sedation (very frequent), depression, dry mouth, } \\
\text { rebound hypertension, hypotension (rare), } \\
\text { confusion (with high doses), Localized irritation } \\
\text { with transdermal preparation }\end{array}$ \\
\hline Guanfacine & $\begin{array}{l}\text { I5-43 } \mu \mathrm{g} / \mathrm{kg}(0.5-4.0 \mathrm{mg} / \text { day }) \text { in I-2 } \\
\text { divided doses }\end{array}$ & $\begin{array}{l}\text { Same as clonidine but much less sedation, less } \\
\text { hypotension }\end{array}$ \\
\hline \multicolumn{3}{|c|}{ Norepinephrine reuptake inhibitors } \\
\hline Atomoxetine & $0.5-1.4 \mathrm{mg} / \mathrm{kg} /$ day in $\mathrm{I}-2$ divided doses & $\begin{array}{l}\text { Decreased appetite, dyspepsia, dizziness, fatigue, } \\
\text { sedation, nausea emesis, mood swings, growth delay }\end{array}$ \\
\hline
\end{tabular}

Adapted with permission from Greydanus DE, Sloane MA, Rappley MD. Psychopharmacology of ADHD in adolescents. Adolesc Med. 2002;13:599-624." Copyright @ 2002 Elsevier. 
Table 2 Methylphenidate preparations

\begin{tabular}{|c|c|c|c|c|c|}
\hline \multirow{2}{*}{$\begin{array}{l}\text { Brand name } \\
\text { (in USA) }\end{array}$} & \multirow[t]{2}{*}{ Dosage form } & \multicolumn{3}{|l|}{ Dosing regimen } & \multirow{2}{*}{$\begin{array}{l}\text { Duration of } \\
\text { effect in hours }\end{array}$} \\
\hline & & Start & Titrate weekly & Maximum per day & \\
\hline \multicolumn{6}{|c|}{ Active ingredient: $\mathrm{d}, \mathrm{I}$, methylphenidate } \\
\hline $\begin{array}{l}\text { Ritalin; generic } \\
\text { form available }\end{array}$ & Scored tablets: 5, 10, 20 mg & $\begin{array}{l}5 \text { mg } 2-3 \text { times/day; } \\
\text { I dose before break- } \\
\text { fast, I before lunch }\end{array}$ & $\begin{array}{l}5-10 \mathrm{mg} \text {; Give a third } \\
\text { dose in the afternoon if } \\
\text { needed }\end{array}$ & $\begin{array}{l}\text { Not to exceed } \\
20 \mathrm{mg} / \text { dose; } 60 \mathrm{mg} / \text { day }\end{array}$ & $3-4$ \\
\hline Ritalin SR & $\begin{array}{l}\text { Sustained release tablets: } \\
20 \mathrm{mg}\end{array}$ & $20 \mathrm{mg}$ before breakfast & $\begin{array}{l}20 \mathrm{mg} \text {; Give a second } \\
\text { dose in afternoon if } \\
\text { needed; for desired } \\
\text { dose and duration, } \\
\text { short acting form may } \\
\text { be used }\end{array}$ & $60 \mathrm{mg}$ & $6-8$ \\
\hline Ritalin LA & $\begin{array}{l}\text { Long-acting capsules; 10, 20, } \\
30,40 \text { mg; can be sprinkled }\end{array}$ & $10 \mathrm{mg}$ before breakfast & $\begin{array}{l}5-10 \mathrm{mg} \text {; use short } \\
\text { acting form (Ritalin) to } \\
\text { titrate if needed }\end{array}$ & $60 \mathrm{mg}$ & $4-8$ \\
\hline Methylin & $\begin{array}{l}\text { Scored tablets: } 5,10 \text {, } \\
20 \mathrm{mg} \text {; chewable tablets: } \\
2.5,5,10 \mathrm{mg} \text {; oral solution: } \\
5 \mathrm{mg} / \mathrm{mL}, 10 \mathrm{mg} / 10 \mathrm{~mL}\end{array}$ & $\begin{array}{l}5 \mathrm{mg} 2-3 \text { times/day; } \\
\text { I dose before } \\
\text { breakfast, I before } \\
\text { lunch }\end{array}$ & $\begin{array}{l}5-10 \mathrm{mg} \text {; Give a third } \\
\text { dose in the afternoon if } \\
\text { needed }\end{array}$ & $\begin{array}{l}\text { Not to exceed } \\
20 \mathrm{mg} / \text { dose; } 60 \mathrm{mg} / \text { day }\end{array}$ & $3-4$ \\
\hline Methylin ER & $\begin{array}{l}\text { Extended release tablets: } \\
10,20 \mathrm{mg}\end{array}$ & $10 \mathrm{mg}$ before breakfast & $\begin{array}{l}10 \mathrm{mg} \text {; give a second } \\
\text { dose in afternoon if } \\
\text { needed }\end{array}$ & $60 \mathrm{mg}$ & $4-8$ \\
\hline Metadate ER & $\begin{array}{l}\text { Extended release tablets: } \\
10,20 \mathrm{mg}\end{array}$ & $10 \mathrm{mg}$ before breakfast & $\begin{array}{l}10 \mathrm{mg} \text {; Give a second } \\
\text { dose in afternoon if } \\
\text { needed }\end{array}$ & $60 \mathrm{mg}$ & $4-8$ \\
\hline Metadate CD & $\begin{array}{l}\text { Extended release capsules: } \\
\text { 10,20,30 mg. Can be } \\
\text { sprinkled }\end{array}$ & $20 \mathrm{mg}$ before breakfast & $\begin{array}{l}20 \mathrm{mg} \text {; Give a second } \\
\text { dose in the afternoon if } \\
\text { needed }\end{array}$ & $60 \mathrm{mg}$ & $4-8$ \\
\hline Concerta & $\begin{array}{l}\text { Capsules: I8, 27, 36, } 54 \mathrm{mg} \\
\text { do not split or chew or } \\
\text { crush }\end{array}$ & $18 \mathrm{mg}$ before breakfast & $18 \mathrm{mg}$ & $72 \mathrm{mg}$ & $8-12$ \\
\hline Daytrana & $\begin{array}{l}\text { Transdermal patch: 10, 15, } \\
20,30 \mathrm{mg}\end{array}$ & $\begin{array}{l}10 \mathrm{mg} \text { patch applied } \\
2 \text { hour before desired } \\
\text { effect; remove } 9 \text { hours } \\
\text { later }\end{array}$ & $10 \mathrm{mg}$ & $30 \mathrm{mg}$ & 12 \\
\hline \multicolumn{6}{|c|}{ Active ingredient: $\mathrm{d}$, methylphenidate } \\
\hline Focalin & Scored tablets: $2.5,5,10 \mathrm{mg}$ & $2.5 \mathrm{mg} \mathrm{I}-2$ times a day & $\begin{array}{l}2.5 \mathrm{mg} \text {; Give a third } \\
\text { dose in afternoon if } \\
\text { needed. }\end{array}$ & $30 \mathrm{mg}$ & $4-6$ \\
\hline Focalin XR & $\begin{array}{l}\text { Extended release capsules: } \\
5,10 \mathrm{mg} \text {; can be sprinkled }\end{array}$ & $5 \mathrm{mg}$ before breakfast & $\begin{array}{l}5 \mathrm{mg} \text {; Give a second } \\
\text { dose in afternoon if } \\
\text { needed; for desired } \\
\text { dose and duration short } \\
\text { acting form (Focalin) } \\
\text { may be used }\end{array}$ & $30 \mathrm{mg}$ & $8-12$ \\
\hline
\end{tabular}

Reproduced from Greydanus DE, Calles JL, Patel DR. Pediatric and Adolescent Psychopharmacology. Cambridge, England: Cambridge University Press; 2008. p. 83-84. ${ }^{14}$

10 to $30 \mathrm{mg}$ of MPH depending on the patch size used. ${ }^{1,14-16}$ Approximately half the patients develop some type of skin reaction. Ritalin $\mathrm{LA}^{\circledR}$ is an $\mathrm{MPH}$ capsule manufactured as a $20 \mathrm{mg}, 30 \mathrm{mg}$, and $40 \mathrm{mg}$ capsule with similar amounts of IR (immediate release) and SR (sustained release) beads that result in release of MPH up to 8 hours as if two IR formulations were taken 4 hours apart. ${ }^{1,14}$ The recommended practice is to begin with a daily $20 \mathrm{mg}$ capsule and slowly increase if needed to the $40 \mathrm{mg}$ capsule. Metadate $\mathrm{CD}^{\mathrm{TM}}$ is produced as a $20 \mathrm{mg}$ MPH capsule with coated beads that 
Table 3 Reasons for failure of benefit from stimulant medication

I. ADHD is not the actual diagnosis

2. Concomitant disorders override any observable stimulant benefit

3. Failure to use the proper dose (too high or low)

4. Refusal of child, adolescent, and/or parent to accept medications

5. ADHD type does not respond to stimulants or any medications

6. Side effects of $\mathrm{MPH}$ and/or amphetamines are not tolerated by the patient

7. Failure to start with a low dose and titrate slowly

8. Use of the medication for other than amelioration of attentional dysfunction

(ie, use of stimulants to alter negative behavior as seen with conduct disorders)

allows immediate release of $30 \%$ of the MPH and sustained release of the remaining MPH over 6 to 10 hours. Begin with the $20 \mathrm{mg}$ capsule and carefully titrate to $60 \mathrm{mg}$ a day if necessary.

Focalin $^{\circledR}$ (dexmethylphenidate hydrochloride) is the d-threo-enantiomer of racemic $\mathrm{MPH}$ that is produced as $2.5 \mathrm{mg}, 5 \mathrm{mg}$, and $10 \mathrm{mg}$ tablets lasting 4 to 6 hours; it is developed in formulations that are half the dose of regular MPH and is based on the concept that the d-threo-enantiomer is more active pharmacologically than the 1-threo-enantiomer. Methylin ${ }^{\circledR}$ is another short-acting MPH product produced as 5, 10, and $20 \mathrm{mg}$ tablets while Methylin ER is an extended MPH product made in 10 and $20 \mathrm{mg}$ tablets for an effect lasting up to 8 hours.

Concerta $^{\circledR}$ is a sustained release MPH product that uses the OROS mechanism or osmotic release process in which there is a tri-layer core covered by a semi-permeable membrane with a laser-drilled hole on one end. ${ }^{1,14}$ There is both immediate release of MPH (22\%) from the overcoat and then a gradual release of MPH lasting up to 10 to 16 hours. Concerta $^{\circledR}$ comes as $18 \mathrm{mg}, 36 \mathrm{mg}$, and $54 \mathrm{mg}$ capsules taken once a day. One advantage of this product is that it is very difficult if not impossible to alter it for consumption as an illicit drug to develop euphoric effects.

\section{Amphetamines}

\section{General considerations}

Amphetamines have been known in medical and biochemical circles since the late 1800 s and the first observation of their beneficial impact on attentional dysfunction in children dates back to Bradley's 1937 publication on Benzedrine. ${ }^{35}$ Research over the past several decades has noted that dextroamphetamine (Dexedrine ${ }^{\circledR}$; Dextrostat ${ }^{\circledR}$ ) is another psychostimulant that improves concentration in children, adolescents, and adults. It can be used in place of or as an alternative to MPH for pharmacologic management of ADHD. Effects of this medication last for 3 to 6 hours with an average of 5 hours. Pharmacologic action is due to CNS dopamine rise because of dopamine transporter binding. ${ }^{14,20}$ Side effects are similar to those of MPH products including the well-known addiction potential.

\section{Amphetamine products}

Table 7 lists available amphetamine formulations. Dextroamphetamine is available in $5 \mathrm{mg}$ and $10 \mathrm{mg}$ scored tablets and is prescribed 1 to 3 times a day as needed; generic formulations are also produced. As with MPH, careful titration is recommended to find the best dosage plan for each patient and 40 to $50 \mathrm{mg}$ a day should not be exceeded. A formulation lasting 8 to 10 hours is also noted, Dexedrine ${ }^{\circledR}$ Spansule $^{\circledR}$, and it is available in $5 \mathrm{mg}, 10 \mathrm{mg}$, and $15 \mathrm{mg}$ capsules. Sometimes these short-acting and long-acting formulations can be combined as well for optimal improvement of ADHD symptoms.

Another short-acting amphetamine version is methamphetamine $\left(\right.$ Desoxyn $\left.^{\circledR}\right)$ sold in $5 \mathrm{mg}$ tables that provide effects for 4 hours. However, it has the highest addiction record of all the prescription amphetamines and is difficult to find in the United States. A newer long-acting formulation of dextroamphetamine, Vyvanse ${ }^{\circledR}$ (lisdexamfetamine), has been available since 2007 and provides benefit for up to 12 hours in a constant rate release and with reduced risks of addiction and overdose. , $^{1,36,37}$

Adderall $^{\circledR}$, another long-acting amphetamine, is a mixedsalts amphetamine product with $25 \%$ of the 1 -isomer and $75 \%$ of the d-isomer that lasts 8 to 12 hours; it is produced in scored tablets of various dosage strengths: $5 \mathrm{mg}, 7.5 \mathrm{mg}$, $10 \mathrm{mg}, 12.5 \mathrm{mg}, 15 \mathrm{mg}, 20 \mathrm{mg}$, and $30 \mathrm{mg}$. A longer acting version is Adderall $\mathrm{XR}^{\circledR}$ that produces a pulsed amphetamine salts release with stimulant effects up to 12 hours; it is produced as $5 \mathrm{mg}, 10 \mathrm{mg}, 15 \mathrm{mg}, 20 \mathrm{mg}, 25 \mathrm{mg}$, and $30 \mathrm{mg}$ capsules.

\section{Pemoline}

Pemoline (magnesium pemoline) is a psychostimulant of historical significance as it was available as a long-acting stimulant for several decades. ${ }^{\mathbf{1} 14}$ This medication was taken as a once a day dose and is no longer produced in the United States because of a rare, but well-known development of irreversible liver failure. Informed, written consent for its prescription that overtly acknowledges the possibility of liver failure and death is necessary if it is prescribed. 


\section{Stimulant side effects}

Side effects of stimulant medication (MPH or amphetamines) are noted in Table 4 and these can be found in both short-acting and long-acting (sustained release) forms. ${ }^{6,11-14,17-19}$ Table 5 lists contraindications to stimulant use, whether MPH or amphetamine products. Avoidance or improvement in some of these adverse effects may occur with careful titration of these psychostimulants, beginning with a low dose and gradual increase to find the best dosage regimen for each patient.

As many as $75 \%$ of children or adolescents with Tourette's syndrome have concomitant ADHD and having tics is a relative, not absolute contraindication to use of psychostimulants. ${ }^{24-26}$ If the patient feels that the MPH or amphetamine formulation is improving the attentional dysfunction while inducing or worsening tics, adding anti-tic medications such as risperidone, haloperidol, or pimozide may be of benefit. Some clinicians prefer to avoid stimulants in this situation and use anti-ADHD medications that do not worsen tics, such as $\alpha_{2}$ agonists (as clonidine or guanfacine), atomoxetine, or tricyclic antidepressants.

Sudden death has been reported on rare occasions in pediatric and adult patients taking MPH or amphetamine products, and atomoxetine..$^{1,14,27,28}$ Though these medications

Table 4 Potential side effects of methylphenidate

I. Abdominal pain
2. Anorexia
3. Dizziness
4. Headache
5. Insomnia
6. Jitteriness
7. Insomnia (delayed onset of sleep)
8. Social withdrawal
9. Weight loss (due to decreased appetite)
10. Appearance of being "dazed or drugged"; perseveration and withdrawal
II. Appearance of psychosis or psychotic manifestations
12. Change in personality
13. Constipation
14. Dry mouth
15. Increased hyperactivity
16. Increase in blood pressure, pulse, and palpitations
17. Moodiness (irritability)
18. Nausea
19. Rebound phenomenon
20. Skin rash (rare)
21. Tolerance
22. "Unmasking" of Tourette's syndrome

${ }^{\mathrm{a} C}$ Commonly seen side effect.
Table 5 Contraindications to stimulant use

I. Concomitant prescription with MOAs (monoamine oxidase inhibitors)

2. Glaucoma

3. Hyperthyroidism

4. Medication sensitivity

5. Overt cardiovascular disease

6. Psychosis

7. Substance abuse disorders

8. Uncontrolled hypertension

are not known to be a direct cause of sudden death, they should be avoided in patients who have overt or symptomatic cardiovascular disease or uncontrolled hypertension. The American Heart Association has recommended that all children placed on stimulant medications for ADHD should receive a screening EKG; however, the American Academy of Pediatrics has concluded that this is neither necessary nor recommended. ${ }^{27,28}$ Recommendations for cardiovascular screening and stimulant use appear in Table 6.

Psychostimulants may induce mania in one with latent bipolar disorder or psychosis in one with latent schizophrenia. Interaction between MPH products and some anticonvulsants, including phenobarbital, phenytoin, and ethosuximide may occur. Most studies conclude that use of psychostimulants does not induce substance abuse disorder, though stimulants can be abused for euphoric effects. ${ }^{29-32}$ Thus, only those with clear evidence of ADHD should be prescribed psychostimulants and careful observation should occur to seek to prevent the medication being diverted to others and/or used by the patient for purposes of getting high or selling these drugs. Youth may also use other drugs with stimulant qualities, such as caffeine, nicotine, or cocaine, to self-medicate their attention dysfunction. ${ }^{33,34}$ There is potential for addiction and withdrawal symptoms with all stimulant medications.

Tolerance occurs in some children or adolescents taking high stimulant doses and this phenomenon may improve with use of a different stimulant or lowering the dose of the same medication. Another phenomenon that has been seen in some on psychostimulant medication is rebound, in which the ADHD symptoms worsen when the medication is reduced or blood levels drop after the ingestion of the last dose. ${ }^{1,14}$ Changing the current combination of short-acting and/or long-acting stimulant may ameliorate rebound. Rebound noted in the early evening is difficult to correct and sleep disturbances may result. Sleep dysfunction occurs in a number of those taking stimulants, especially the longacting formulations. Stimulant-induced sleep disturbances 
Table 6 Cardiovascular screening

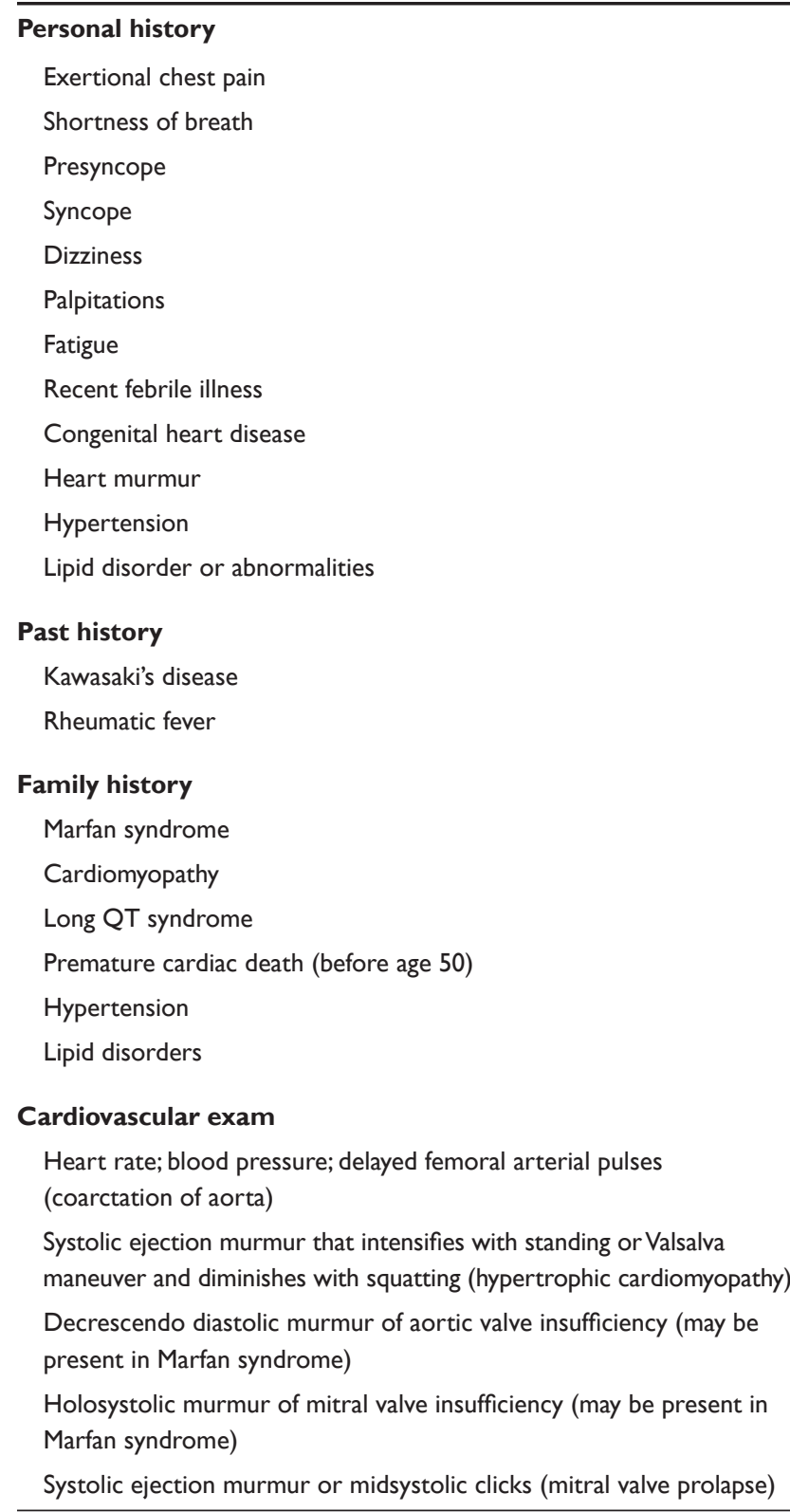

Reproduced from Greydanus DE, Calles JL, Patel DR. Pediatric and Adolescent Psychopharmacology. Cambridge, England: Cambridge University Press; 2008. p. 91.14

may improve by avoidance of sustained release stimulants, avoidance of all stimulant formulations in the afternoon or evening, and/or the addition of various sedative medications before bedtime, such as trazodone $(25-50 \mathrm{mg})$, melatonin (3-6 mg), or mirtazepine $\left(\right.$ Remeron $\left.^{\circledR}\right)(7.5-15 \mathrm{mg})$.

\section{Norepinephrine reuptake inhibitors} Atomoxetine

Atomoxetine, along with methylphenidates and amphetamines, are the only FDA-approved medications for ADHD.
Atomoxetine is a norepinephrine reuptake inhibitor that blocks the presynaptic norepinephrine transporter in the prefrontal cortex without primary effects on dopamine levels. ${ }^{38-42}$ It has been recommended for those with ADHD where psychostimulants are not desired, tolerated, or effective. ${ }^{6,41} \mathrm{It}$ is a non-stimulant anti-ADHD medication available since 2003 and produced in a variety of capsule strengths: $10 \mathrm{mg}$, $18 \mathrm{mg}, 25 \mathrm{mg}, 40 \mathrm{mg}$, and $60 \mathrm{mg}$. The recommended starting dose for the child $70 \mathrm{~kg}$ or less is $0.5 \mathrm{mg} / \mathrm{kg} /$ day that is increased at least every 3 days to $1.2 \mathrm{mg} / \mathrm{kg}$ /day given as a single dose or in 2 divided doses. The maximum dose should not exceed $1.4 \mathrm{mg} / \mathrm{kg} /$ day or $100 \mathrm{mg}$ per day. The duration of effect is 18 to 24 hours.

Side effects of atomoxetine are listed in Table $8 .^{38-42}$ There are drug-to-drug interactions that involve selective serotonin reuptake inhibitors and others metabolized by cytochrome P450 2D6; it has a low affinity for various receptors, such as serotonergic, cholinergic, histaminic, alpha ${ }_{1}$-adrenergic, and alpha ${ }_{2}$-adrenergic. Cardiovascular complications, tics, drug diversion, and drug addiction are not associated with atomoxetine. The US FDA issued a black box warning for use of atomoxetine because of an increase in suicidality in patients taking this medication..$^{41}$ Children and adolescents who are placed on this medication should be observed for the next few months for agitation, suicidality, or irritability that occur with drug initiation or dosage change. There is an increase risk for mydriasis and it must be avoided in those with narrow angle glaucoma. Baseline liver function tests and periodic monitoring are necessary because of anecdotal reports of severe liver injury. Studies are currently evaluating the potential added benefit of atomoxetine taken with stimulants.

\section{Alpha-2 agonists General considerations}

Alpha $_{2}$-adrenergic agonists (such as clonidine or guanfacine) have been noted to be beneficial for some patients with ADHD because of their sedative effects helping to combat the sleep dysfunctional aspects of MPH. ${ }^{1,6,11,12,18}$ Those who have only attentional dysfunction may develop impaired neuropsychological effects if placed on clonidine or guanfacine.

\section{Clonidine}

Clonidine is available as a pill and patch in three dosages: $0.1 \mathrm{mg}, 0.2 \mathrm{mg}$, and $0.3 \mathrm{mg}$; the pill formulation is prescribed 2 to 4 times a day or at bedtime starting with the lowest formulation. 
Table 7 Amphetamine preparations

\begin{tabular}{|c|c|c|c|c|c|}
\hline \multirow{2}{*}{$\begin{array}{l}\text { Brand name } \\
\text { (in USA) }\end{array}$} & \multirow[t]{2}{*}{ Dosage form } & \multicolumn{3}{|l|}{ Dosing regimen } & \multirow{2}{*}{$\begin{array}{l}\text { Duration of } \\
\text { effect (hours) }\end{array}$} \\
\hline & & Start & $\begin{array}{l}\text { Titrate } \\
\text { weekly }\end{array}$ & $\begin{array}{l}\text { Maximum } \\
\text { per day }\end{array}$ & \\
\hline \multicolumn{6}{|c|}{ Active ingredient: Dextroamphetamine } \\
\hline $\begin{array}{l}\text { Dexedrine (generic } \\
\text { form available) }\end{array}$ & Tablets: $5 \mathrm{mg}$ & $5 \mathrm{mg} \mathrm{I}-2$ times/day & $5 \mathrm{mg}$ & $40 \mathrm{mg}$ & $4-6$ \\
\hline Dextrostat & Scored tablets: $5,10 \mathrm{mg}$ & $2.5-5 \mathrm{mg} \mathrm{I}-2$ times/day & $5 \mathrm{mg}$ & $40 \mathrm{mg}$ & $4-6$ \\
\hline Generic form & $\begin{array}{l}\text { Extended release capsules: } \\
5,10,20 \mathrm{mg}\end{array}$ & $5 \mathrm{mg} \mathrm{I-2} \mathrm{times/day}$ & $5 \mathrm{mg}$ & $40 \mathrm{mg}$ & $4-6$ \\
\hline $\begin{array}{l}\text { Dexedrine } \\
\text { Spansule }\end{array}$ & $\begin{array}{l}\text { Spansules: } 5,10,15 \mathrm{mg} \text {; can } \\
\text { be sprinkled }\end{array}$ & $5 \mathrm{mg}$ before breakfast & $5 \mathrm{mg}$ & $45 \mathrm{mg}$ & $6-10$ \\
\hline \multicolumn{6}{|c|}{ Active ingredient: Mixed salts of amphetamine (dextroamphetamine plus levoamphetamine) } \\
\hline $\begin{array}{l}\text { Adderall (generic } \\
\text { form available) }\end{array}$ & $\begin{array}{l}\text { Tablets: } 5,7.5,10,12.5,15 \text {, } \\
20,30 \mathrm{mg}\end{array}$ & $\begin{array}{l}\text { 5-10 mg I-2 times/day; } \\
\text { I dose before breakfast, } \\
\text { second before lunch }\end{array}$ & $5-10 \mathrm{mg}$ & $40 \mathrm{mg}$ & $4-6$ \\
\hline Adderall $\mathrm{XR}$ & $\begin{array}{l}\text { Extended release capsules: } \\
5,10,15,20,25,30 \mathrm{mg} \text {; can } \\
\text { be sprinkled }\end{array}$ & $\begin{array}{l}5-10 \mathrm{mg} \text { before } \\
\text { breakfast }\end{array}$ & $5-10 \mathrm{mg}$ & $30 \mathrm{mg}$ & $8-12$ \\
\hline
\end{tabular}

Reproduced from Greydanus DE, Calles JL, Patel DR. Pediatric and Adolescent Psychopharmacology. Cambridge, England: Cambridge University Press; 2008. p. 85.

The dosage range for clonidine is 0.05 to $0.4 \mathrm{mg}$ and it is important to slowly titrate the medication to reduce potential side effects, as listed in Table 9. Slow reduction of clonidine is recommended when stopping this drug to reduce the possibility of rebound hypertension. The patch formulation is effective for 3 to 7 days and local dermatitis may occur in a few using the patch. Use of the clonidine patch may prevent or ameliorate sedative as well as blood pressure effects seen with the oral formulation. Baseline studies before starting this medication include a blood pressure, pulse, blood glucose,

Table 8 Potential atomoxetine side effects

\begin{tabular}{l} 
Anorexia \\
Constipation \\
Dizziness \\
Dry mouth \\
Dyspepsia \\
Emesis \\
Fatigue \\
Heightened pulse and blood pressure \\
Mood swings (FDA Black Box warning on increased suicidal thinking in \\
children and adolescents) \\
Nausea up to several weeks \\
Sedation or insomnia \\
Sexual dysfunction \\
Voiding difficulty \\
\hline
\end{tabular}

and an electrocardiogram (EKG); such testing may be repeated periodically, especially if changing doses. An EKG can be done every 6 months if the child or adolescent remains on clonidine. There are reports of a few cases of sudden deaths in pediatric patients taking MPH and clonidine.

\section{Guanfacine}

This is an alpha ${ }_{2 \mathrm{~A}}$-adrenergic agonist that may lead to less sedation and hypotension compared with clonidine. ${ }^{11,12,18} \mathrm{In}$ addition, there may be increased prevalence of headaches and agitation with use of guanfacine. This medication is available as $1 \mathrm{mg}$ and $2 \mathrm{mg}$ tablets while the daily dosage range is $0.5 \mathrm{mg}$ to $4 \mathrm{mg}$. Guanfacine XR is an extended release form that is being considered for ADHD management in pediatric patients. ${ }^{43,44}$

\section{Antidepressants Tricyclic antidepressants (TCAs)}

An alternative to psychostimulants for several decades has been TCAs as listed in Table $10^{1,6,11,12,14}$ while Table 11 lists potential side effects of TCAs. Children or adolescents placed on TCAs should be carefully monitored with vital signs, complete blood count, serum TCA levels, and an EKG. Protocols for management have been published. ${ }^{45-47}$ Sudden deaths have been rarely reported in pediatric patients taking both TCAs and MPH. ${ }^{45,46}$ 
Table 9 Side effects of clonidine

Sedation (50\%)

Attentional dysfunction

Dry mouth

Headache

Depression

Dizziness

Dysphoria

Effects that are not consistent

Fatigue

Irritability

Itchy eyes

Neuroleptic anticholinergic side effects potentiation

Patch-induced dermatitis

Postural hypotension

Rebound phenomenon

Reduced glucose tolerance

Tolerance

Weight gain

Withdrawal effects due to sudden cessation leading to severe hypertension and rebound tachycardia

Worsening of pre-existing cardiac arrhythmias

\section{Bupropion}

Another antidepressant that has been used to manage attentional dysfunction of ADHD is bupropion (Table 1), a medication also used to treat tobacco addiction as the formulation $\mathrm{Zyban}^{\mathrm{TM}}$ in addition to depression and ADHD as Wellbutrin ${ }^{\circledR} \cdot{ }^{32,48,49}$ It is available as 75 and $100 \mathrm{mg}$ tablets and the daily dosage range is 50 to $300 \mathrm{mg}$ for depression and ADHD - not over $6 \mathrm{mg} / \mathrm{kg}$ per day. Other bupropion preparations include two sustained release formulations Wellbutrin $\mathrm{SR}^{\circledR}$ (100 mg and $150 \mathrm{mg}$ ) given twice a day and Wellbutrin $\mathrm{XL}^{\circledR}$ given once a day.

Table 12 lists side effects of bupropion and includes seizures with an incidence of $0.1 \%$ if the dosage is less than $300 \mathrm{mg}$ per day and $0.4 \%$ if over $300 \mathrm{mg}$ a day. ${ }^{14} \mathrm{Head}$ trauma, epilepsy, and bulimia nervosa are contraindications for bupropion. Also, the risks for seizure activity is lessened by slow drug titration, avoidance of taking it less than 8 hours

Table 10 Tricyclic antidepressants

\begin{tabular}{ll}
\hline Tricyclic antidepressants & Dosage range \\
\hline Imipramine $\left(\right.$ Tofrani $^{\circledR}$, others & $50-200 \mathrm{mg} /$ day \\
Desipramine $\left(\right.$ Norpramin $^{\circledast}$, Desipramine $^{\circledR}$ ) & $50-200 \mathrm{mg} /$ day \\
Amitriptyline $\left(\right.$ Elavi $\left.^{\circledR}\right)$ & $50-200 \mathrm{mg} /$ day \\
Nortriptyline $\left(\right.$ Pamelor $\left.^{\circledR}\right)$ & $20-100 \mathrm{mg} /$ day \\
\hline
\end{tabular}

apart, avoidance of prescription for high amounts of the regular formulation, and prescription of the sustained release formulations. One benefit of bupropion is that interactions with other medications are of minimal significance, except for the interaction with MAOIs. Bupropion is metabolized by the cytochrome P450 system and has the potential to interact with other agents that affect the 2B6 isoenzyme (ie, desipramine, paroxetine, sertraline, others). It does carry an FDA black box warning about suicidality though it does not lead to cardiac conduction delays as noted with TCAs.

\section{Venlafaxine}

Venlafaxine is an atypical antidepressant that some clinicians use for ADHD and is considered a second or third-line agent. ${ }^{1,14,50}$ It selectively inhibits norepinephrine and serotonin reuptake and weakly inhibits dopamine uptake. It is available in 25, 50, 75, and $100 \mathrm{mg}$ tablets for oral administration. The dosage is 1 to $3 \mathrm{mg} / \mathrm{kg} / \mathrm{day}$ or 37.5 to $225 \mathrm{mg} /$ day. As with the use of other antidepressants, it is important to observe children and adolescents on venlafaxine for the risk of suicidality. Sustained hypertension, which is dose-related, may occur in patients receiving this antidepressant. Since mydriasis may occur, venlafaxine can be harmful to a patient with increased intraocular pressure or one at risk for acute narrow-angle glaucoma. Drug interactions with MAOIs are well-known. Venlafaxine is metabolized by numerous isoenzymes of the cytochrome P450 system and has the potential for multiple drug interactions. Caution should be exercised when adding medications to venlafaxine. It is contraindicated in individuals with heart disease.

\section{Modafinil}

A newer antidepressant is modafinil, which acts in many ways like the sympathomimetic agents; however, it is unique in that it does not bind to catecholamine receptors nor increase adrenergic activity. ${ }^{51-55}$ Its exact mechanism of promoting alertness and wakefulness is unknown, though it has pharmacologic effects in the thalamus, hippocampus, and central nucleus of the amygdala. Current FDA approved uses include narcolepsy and obstructive sleep apnea/hypopnea syndrome (OSAHS). ${ }^{14}$ It has not been FDA-approved for children and adolescents with ADHD. Modafinil is available for oral administration as $100 \mathrm{mg}$ and $200 \mathrm{mg}$ tablets. Typical dosing in children with ADHD is 50 to $100 \mathrm{mg}$ daily.

Some common side effects include headache, gastrointestinal disturbances, nervousness, dizziness, anxiety (doserelated), and insomnia. As with other stimulants, modafinil can be harmful to patients with a history of cardiovascular 
Table I I Potential tricyclic antidepressant side effects

Dizziness
Drowsiness and sedation
Confusion
Constipation
Hypotension
Increase in heart rate (10-15 beats per minute)
and blood pressure (up to 8-10 mmHg)
EKG changes (sinus tachycardia,AV blocks, increased QRS interval,
increased QTc interval)
Exercise-induced tachycardia
Blurred vision (including cycloplegia and mydriasis)
Cholestatic jaundice
Dry mouth (with decreased salivary flow and increased tooth decay)
Lowered seizure threshold
Delirium (in high doses)
Drug interactions (as with selective serotonin reuptake inhibitors)
Skin rash
Sudden death
Tachycardia
Urinary retention
Weight gain
Priapism
Respiratory failure and death from an overdose
Blood dyscrasias
Peripheral neuropathy

disease or Tourette's syndrome and caution should be used in patients with a history of psychosis. Modafinil has the propensity for drug interactions since it is metabolized by the cytochrome P450 system and can act as an inducer or inhibitor of the cytochrome P450 system.

\section{Medications for the future}

Future research will divide ADHD into various subtypes depending on a more precise knowledge of what parts of the CNS are involved as classification of ADHD becomes

Table 12 Potential side effects of bupropion

\begin{tabular}{l} 
Anorexia \\
Agitation \\
Drowsiness \\
Headaches \\
Nausea \\
Restlessness \\
Seizures ( $0.1 \%$ under $300 \mathrm{mg}$ a day and $0.4 \%$ over $300 \mathrm{mg}$ a day) \\
Tics (exacerbation) \\
\hline
\end{tabular}

more sophisticated. ${ }^{1}$ This will allow the development of additional medications targeted at specific CNS pathways. ${ }^{56}$ Long-acting formulations of drugs already used for ADHD management will continue to be developed and utilized. ${ }^{57}$ However, careful titration is important for each patient, since some do best with short-acting stimulants, others with long-acting stimulants, and still others with a combination of both. ${ }^{14,58}$

AMPA (ampakines) receptor modulators (such as CX-717) are used as memory enhancer drugs and may be utilized in the future as beneficial anti-ADHD drugs. ${ }^{1,59,60}$ Nicotinic acetylcholine receptor antagonists are also under current research as medication to enhance attentional dysfunction in ADHD patients. ${ }^{60-62}$ Dopamine agonists (such as ropinirole) are used to treat restless legs syndrome and have been shown to improve attention span. ${ }^{63-65}$ Atypical antipsychotics (such as aripiprazole and risperidone) are being researched as anti-ADHD drugs especially if there are co-morbidities present as conduct disorder or bipolar disorder. ${ }^{66,67}$ Studies are also evaluating the potential role of selective noradrenaline reuptake inhibitors (such as reboxetine mesylate) for ADHD management. ${ }^{68}$ Finally, GABA B receptor antagonists (such as SGS-742) are being studied as potential anti-ADHD drugs. ${ }^{60}$

\section{Summary}

US FDA medications approved to treat ADHD in children and adolescents include methylphenidate and amphetamine products in addition to atomoxetine. Other medications used for ADHD management include alpha-2 agonists, antidepressants (tricyclic antidepressants, bupoprion, and venlafaxine), and modafinil. ${ }^{1,14}$ Despite intense pharmacologic advertisements, there are no short-acting or long-acting psychostimulants that are proven to be superior to the others. ${ }^{1,14,36,41,69-72}$ All these drugs have adverse effects and a careful titration of these medications with the individual patient is necessary for optimal drug efficacy and patient safety. ${ }^{73-75}$ The future looks promising for the development of newer anti-ADHD drugs in the 21 st century.

\section{Disclosures}

The authors disclose no conflicts of interest.

\section{References}

1. Greydanus DE, Pratt HD, Patel DR. Attention deficit hyperactivity disorder across the lifespan. Dis A Month. 2007;53(2):65-132.

2. Mayes R, Bagwell C, Erkulwater J. Medicating Children: ADHD and Pediatric Mental Health. Cambridge, Massachusetts: Harvard University Press; 2009.

3. Barkley RA. Attention-deficit/hyperactivity disorder. Sci Am. 1998; 66-71. 
4. Soileau EJ. Medications with adolescents with attention-deficit/ hyperactivity disorder. Adolesc Med. 2008;19:254-267.

5. Wolraich ML, Wibbelsman CJ, Brown TE, et al. Attention deficit/ hyperactivity disorder among adolescents. Pediatrics. 2005; 115:1734.

6. Staufer WB, Greydanus DE. Attention-deficit/hyperactivity disorder: Psychopharmacology for college students. Pediatric Clin North Am. 2005;52:71-84.

7. Biederman J, Faraone SC. Attention-deficit hyperactivity disorder. Lancet. 2005;367:237-248.

8. Robin A, Schubiner H, Coleman WL, eds. ADHD/learning disorders. Adolesc Med. 2008;19(2):209-356.

9. Epstein JN, Langberg JM, Lichtenstein PK, et al. Community-wide intervention to improve the attention-deficit/hyperactivity disorder assessment and treatment practices of community physicians. Pediatrics. 2008;122:19-27.

10. Mayes R, Rafalovich A. Suffer the restless children: the evolution of ADHD and paediatric stimulant use: 1900-1980. Hist Psychiatry. 2007;18(72 Pt 4):435-457.

11. Greydanus DE, Sloane MA, Rappley MD. Psychopharmacology of ADHD in adolescents. Adolesc Med. 2002;13:599-624.

12. Greydanus DE, Pratt HD, Sloane MA, et al. Attention-deficit/ hyperactivity disorder in children and adolescents: Interventions for a complex costly clinical conundrum. Pediatr Clin North Am. 2003;50: 1049-1092.

13. Hammerness P, Surman C, Miller K. Update on adult ADHD. Curr Neurol. Neurosci Rep. 2008;8:849-859.

14. Greydanus DE, Calles JL, Patel DR. Pediatric and Adolescent Psychopharmacology. Cambridge, England: Cambridge University Press; 2008

15. Pierce D, Dixon CM, Wigal SB, et al. Pharmacokinetics of methylphenidate transdermal system (MTS): results from a classroom study. J Child Adolesc Psychopharmacol. 2008;18:355-364.

16. Patrick KC, Straughn AB, Perkins JS, González MA. Evolution of stimulants to treat ADHD: transdermal methylphenidate. Hum Psychopharmacol. 2009;24(1):1-17.

17. Greydanus DE. Pharmacologic treatment of attention-deficit/ hyperactivity disorder. Indian J Pediatrics. 2005;72:27-34

18. Greydanus DE, Pratt HD. ADHD in children and adolescents. In: Greydanus DE, Patel DR, Pratt HD, eds. Behavioral pediatrics, 2nd ed. New York: iUniverse Publishers; 2006.

19. Silva RR, Munix R, Pestreich L, et al. Dexmethylphenidate extended release capsules in children with attention-deficit/hyperactivity disorder. J Am Acad Child Adolesc Psychiatry. 2008;47:199-208.

20. Solanto MV, Arnsten AFT, Castellanos FX. The Neuroscience of stimulant drug action in ADHD. In: Solanto MV, Arnsten AFT, Castellanos FX, eds. Stimulant drugs and ADHD. London: Oxford Univ Press, 2001. p. 355-379.

21. Zito JM, Safer DJ, dosReis S, et al. Psychotropic practice patterns for youth. A 10-year perspective. Arch Pediatr Adolesc Med. 2003; 157:17-25.

22. Cox ER, Halloran DR, Homan SM, et al. Trends in the prevalence of chronic medication use in children: 2002-2005. Pediatrics. 2008;122: e1053-e1061

23. Volkow ND, Fowler JS, Wang G, Ding Y, Gatley SJ. Mechanism of action of methylphenidate: insights from PET imaging studies. $J$ Atten Disord. 2002;6(Suppl 1):S31-S43.

24. Tourette's Syndrome Study Group. Treatment of ADHD in children with tics: a randomized controlled trial. Neurology. 2002;58(4): 527-536.

25. Patel DR, Greydanus DE: Neurological conditions and disability in adolescents. Intl J Disabil Hum Dev. 2008;7(3):279-282.

26. Jankovic J. Tourette's syndrome. N Engl J Med. 2001;345:1184-1192.

27. Perrin JM, Friedman RA, Knilans TK, et al. Cardiovascular monitoring and stimulant drugs for attention deficit/hyperactivity disorder. Pediatrics. 2008;122:451-453.
28. Vetter VL, Elia J, Erickson C, et al. Cardiovascular monitoring of children and adolescents with heart disease receiving stimulant drugs. A scientific statement from the American Heart Association Council on Cardiovascular Disease in the Young, Congenital Cardiac Defects Committee and the Council on Cardiovascular Nursing. Circulation. 2008;117:2407-2423

29. Fone KCF, Nutt DJ. Stimulants: use and abuse in the treatment of attention deficit hyperactivity disorder. Curr Opin Pharmacol. 2005;5:87-93.

30. Wilens TE, Gignac M, Swezey A, et al. Characteristics of adolescents and young adults with ADHD who divert or misuse their prescribed medications. J Am Acad Child Adolesc Psychiatry. 2006;45:408-414.

31. Wilens TE, Faraone SV, Biederman J, et al. Does stimulant therapy of attention-deficit/hyperactivity disorder beget later substance abuse? A meta-analytic review of the literature. Pediatrics. 2003;111:179-185.

32. Greydanus DE, Patel DR. The adolescent and substance abuse: Current concepts. Curr Probl Pediatr Adolesc Health Care. 2005;35(3):78-98.

33. Bramstedt KA. Caffeine use by children: quest for enhancement. Subst Use Misuse. 2007;42:1237-1251.

34. Gehricke JG, Loughlin SE, Whalen CK, et al. Smoking to self-mediate attentional and emotional dysfunction. Nicotine Tob Res. 2007; 9(Suppl 4):S523-S536.

35. Bradley C. The behavior of children receiving benzedrine. Am J Psychiatry. 1937;577-585.

36. Lisdexafetamine dimesylate (Vyvanse) for ADHD. Med Lett. 2007; 49:58-59.

37. Lopez FA, Ginsberg LD, Arnold V. Effect of lisdexamfetamine dimethylate on parent-rated measures in children aged 6-12 years with attention-deficit hyperactivity disorder: a secondary analysis. Post grad Med. 2008;120:89-102.

38. http:www.fda.gov/medwatch/safety/2005/safety05.htm\#Strattera.

39. Spencer T, Biederman J, Wilens T, et al. Effectiveness and tolerability of atomoxetine in adults with attention-deficit hyperactivity disorder. Am J Psychiatry. 1998;155:693-695.

40. Michelson D, Allen AJ, Busner J, et al. Once-daily atomoxetine treatment for children and adolescents with ADHD: A randomized, placebo-controlled study. Am J Psychiatry. 2002;159:1896-1901.

41. Atomoxetine (Strattera) for ADHD. Med Lett. 2003;45:11-12.

42. Allen AJ, Spencer TJ, Heiligenstein JH, et al. Safety and efficacy of atomoxetine for $\mathrm{AHDH}$ in two double-blind, placebo-controlled trials. Biol Psychiatry. 2001;49(Suppl 8):32S-33S.

43. Biedermann J, Melmed RD, Patel A. Guanfacine extended release for Pediatric Attention deficit/hyperactivity disorder. Pediatrics. 2008;121: e73-e84.

44. Biederman J, Melmed RD, Patel A, et al. A randomized, double-blind, placebo-controlled study of guanfacine extended release in children and adolescents with ADHD. Pediatrics. 2008;121:e73-e84.

45. Varley C. Sudden death of a child treated with imipramine. J Child Adolesc Psychopharmacol. 2000;10:321-325.

46. Varley CK. Sudden death related to selected tricyclic antidepressants in children: Epidemiology, mechanisms and clinical implications. Paediatr Drugs. 2001;3:613-627.

47. Pliszka SR, Greenhill LL, Crismon ML, et al. The Texas Children's Medication Algorithm Project: Report of the Texas Consensus Conference Panel on medication treatment of childhood attention-deficit/hyperactivity disorder. Part I. J Am Acad Child Adolesc Psychiatry. 2001;39:908-919.

48. Daviss WB. Buproprion for adolescents with attention-deficit/ hyperactivity disorder. J Am Acad Child Adolesc Psychiatry. 2001;40: 307-314.

49. Wilkes S. Bupropion. Drugs Today. 2006;42(10):671-681.

50. Findling RL, Greenhill LL, McNamara NK, et al. Venlafaxine in the treatment of children and adolescents with attention deficit hyperactivity disorder. J Child Adolesc Psychopharmacol. 2007;17:433-445.

51. Turner DC, Clark L, Dowson J, et al. Modafinil improves cognition and response inhibition in adult attention-deficit/hyperactivity disorder. Biol Psychiatry. 2004;55:1031-1040. 
52. López FA. ADHD: New pharmacologic treatments on the horizon. J Dev Behav Pediatr. 2006;27:410-416.

53. Biederman J, Pliszka SR. Modafanil improves symptoms of attentiondeficit hyperactivity disorder across subtypes in children and adolescents. J Pediatr. 2008;152:394-399.

54. Ballon JS, Feifel D. A systemic review of modafanil: Potential clinical uses and mechanism of action. J Clin Psychiatr. 2006;67:554-566.

55. Kumar R. Approved and investigational uses of modafanil: An evidence-based review. Drugs. 2008;68:1803-1839.

56. Stein MA, McGough JJ. The pharmacogenomic era: promise for personalizing ADHD therapy. Child Adolesc Psychiatry Clin N Amer. 2008; 17:475-490.

57. Swanson JM, Hechtman L. Using long-acting stimulants: does it change ADHD treatment outcome? Can Child Adolesc Psychiatr Rev. 2005;14(Suppl 1):2-3.

58. Greydanus DE. Metilfenidato: Ventajas de metifenidato de liberacion immediata sobre las formulaciones de metifenidato de liberacion prolongada. Euromedice. 2007;2-3.

59. Danysz W. CX-516 Cortex Pharmaceuticals. Curr Opin Invest Drugs. 2002;3:1081-1088.

60. Weisler RA. Emerging drugs for ADHD. Expert Opin Emerg Drugs. 2007;12:423-434.

61. Levin ED. Nicotinic receptor subtypes and cognitive function. Neurol Biol. 2002;53:633-646.

62. Adler LA, Chua HC. Management of ADHD in adults. J Clin Psychiatr. 2002;63(Suppl 12):29-35.

63. Konofal E, Arnuuf I, Lecendreaux M, Mouren MC. Ropinirole in a child with attention-deficit hyperactivity disorder and restless legs syndrome. Pediatr Neurol. 2005;30:350-351.
64. Finding RL. Evolution of the treatment for attention-deficit hyperactivity disorder in children: a review. Clin Ther. 2008;30:942-951.

65. Karroum E, Konofal E, Arnuuf I. Restless legs syndrome. Rev Neurol. 2008;164:701-721.

66. Findling RL, Short EJ, Leskovec T, et al. Aripiprazole in children with ADHD. J Child Adolesc Psychopharmacol. 2008;18:347-354.

67. Findling RL. Atypical antipsychotic treatment of disruptive behavior disorders in children and adolescents. J Clin Psychiatry. 2008; 69(Suppl 4):9-14.

68. Toren P, Ratner S, Weizman A, et al. Reboxetine maintenance treatment in children with ADHD: A long term follow-up study. J Child Adolesc Psychopharmacol. 2007;17:803-812.

69. A new long-acting methylphenidate (Concerta). Med Lett. 2000;42:80-81.

70. Another long-acting methylphenidate (Metadate CD). Med Lett. 2001; 43:83-84.

71. Dexmethylphenidate (Focalin) for ADHD. Med Lett. 2002;44:45-46.

72. Pliszka S. AACAP Work Group on Quality Issues. Practice parameter for the assessment and treatment of children and adolescents with attention-deficit/hyperactivity disorder. $J$ Am Acad Child Adolesc Psychiatry. 2007;46:894-921.

73. Hechtman L, Greenfield B. Long-term use of stimulants in children with attention deficit hyperactivity disorder: safety, efficacy, and long-term outcome. Paediatr Drugs. 2003;5:787-794.

74. Lerner M, Wigal T. Long-term safety of stimulant medications used to treat children with ADHD. Pediatr Ann. 2008;37:37-45.

75. Calles JL. ADHD in children and adolescents. In: Greydanus DE, Patel DR, Pratt HD, eds. Behavioral Pediatrics, 3rd ed. New York: Nova Science Publishers; 2009. 
